\title{
INFLUENCE OF VARIABLES TO REDUCE THE INTENTION AND BEHAVIOUR PURCHASE GAPS IN ECO-LABEL FOOD PRODUCTS
}

\author{
INFLUENCIA DE LAS VARIABLES PARA REDUCIR LAS BRECHAS DE COMPRA \\ DE INTENCIÓN Y COMPORTAMIENTO EN LOS PRODUCTOS ALIMENTICIOS \\ CON ETIQUETA ECOLÓGICA
}

\author{
Daniel Herrera González \\ Classification: Empirical paper - research \\ Received: April 7, 2020 / Revised: June 16, 2020 / Accepted: June 29, 2020
}

\begin{abstract}
Academic researchers have sought to examine the variables that affect purchasing behaviour and the development of models for ethical consumer behaviour due to the fact that consumers are increasingly aware of the impact that daily food products can have on the environment. As a result, the demand for environmentally friendly food has increased rapidly and the companies have created different eco-labels to encourage consumers to buy their products. However, there is still a large gap between the intent to purchase eco-labeled products and the actual purchasing behaviour. Thus, this paper explains and assesses the extrinsic and intrinsic variables that could reduce the gap between eco-label purchase intention and the actual purchase behaviour for eco-labelled food products based on the TRA theory. The qualitative findings show that product benefits consumer environmental knowledge, consumer environmental awareness and demographic aspects, all which influence or affect the purchase intention for ecolabelled food, while the eco-label type I has no relationship with the intention of purchase for food with eco-label attributes. This paper is very useful for Latin American food companies given that most of the current research has been focused on European countries.
\end{abstract}

Keywords: Consumer behaviour, green consumerism, eco-labeling, theory of reasoned action, green consumption.

\section{Resumen}

Los investigadores académicos han tratado de examinar las variables que afectan el comportamiento de compra y el desarrollo de modelos de comportamiento ético del consumidor frente a productos ecológicos debido a que los consumidores son cada vez más conscientes del impacto que los productos lácteos pueden tener en el medio ambiente. Como resultado, la demanda de alimentos amigables con el medio ambiente ha aumentado rápidamente y las compañías han creado diferentes etiquetas ecológicas para alentar a comprar sus productos. Sin embargo, todavía hay una gran brecha entre la intención de comprar productos con etiqueta ecológica y el comportamiento real de compra. Por tanto, este artículo explica y evalúa las variables extrínsecas e intrínsecas que podrían reducir la intención de compra de la etiqueta ecológica y el comportamiento real de compra de productos alimenticios con el atributo ecológico, el nuevo modelo conceptual se apoya en la teoría TRA. Los resultados cualitativos muestran que los beneficios del producto, el conocimiento ambiental del consumidor, la conciencia ambiental del consumidor y los aspectos

a_Profesor asociado, Universidad EAN, Colombia. Email: daherrera@universidadean.edu.co 
demográficos influyen o afectan la intención de compra de alimentos con etiqueta ecológica, mientras que la etiqueta ecológica tipo I no tiene relación con la intención de compra de alimentos con atributo de etiqueta ecológica. Este artículo es muy útil para las empresas de alimentos de América Latina porque la mayor parte de estas investigaciones actuales se han centrado en países europeos.

Palabras clave: comportamiento del consumidor, consumismo verde, eco etiquetado, teoría de la acción razonada, consumo verde.

\section{Introduction}

Over the past few decades, the green movement has been expanding rapidly into the global market due to the importance of mitigating the effects of global warming, environmental degradation, and the excessive use of non-renewable resources (Chan, 1999; Dagher, Itani \& Kassar, 2015; Follows \& Jobber, 2000; Hartmann \& Ibáñez, 2006; Laroche, Bergeron, \& Barbaro-Forleo, 2001; Tanner \& Kast, 2003). Consumers are increasingly aware of the impact that daily food products can have on the environment; therefore, the demand for eco-labeled products has rapidly increased and is expected to continue rising in the future (Nasir \& Karakaya, 2014). As a result, companies are changing their normal philosophy for a philosophy of environmental management and sustainable production; they are also changing their products for green products, with certificated eco-labels (Pujari, Wright, \& Peattie, 2003; Vermeir \& Verbeke, 2006). Furthermore, investigations demonstrate that consumers are more likely to consider buying their products from companies that show environmental responsibility (Diamantopoulos, Schlegelmilch, \& Sinkovic, 2003; Mohr \& Webb, 2005; Pomering \& Dolnicar, 2009; Vermillion \& Peart, 2010).

Although green consumption has increased, and research shows that there are segments of consumers who intend to make green purchasing decisions, there is still a large gap between purchasing intentions and actual purchasing behaviour (Carrington, Neville \& Whitwell, 2010; Cleveland, Kalamas, \& Laroche, 2005; Devinney, Auger, \& Eckhardt, 2010; Englis \& Phillips, 2013; Papaoikonomou, Ryan, \& Ginieis, 2011). Academic researchers have sought to understand this gap by examining the variables that affect purchasing behaviour and the development of models for ethical consumer behaviour (Carrington et al., 2010; Chan \& Lau, 2000; D’Souza et al., 2007; Finisterra do Paço, Barata Raposo \& Filho, 2009; Hartmann \& Ibáñez, 2006; Rowlands, Parker, \& Scott, 2002).

This document therefore explains and assesses the extrinsic and intrinsic variables using the TRA (Ajzen $\&$ Fishbein, 1980) that could influence the eco-label purchase intention and the actual purchase behaviour. According to Ajzen \& Fishbein (1980), the expected result of the TRA is "to predict behaviour only if the intention has not changed prior to performance of the behaviour" (Kulh \& Beckmann, 1985, p. 13). Therefore, in order to reduce the gap, it is fundamental to reinforce the intention because the correlation between intention and action (purchase) is very significant following the TRA.

\section{Theoretical Framework}

Society is currently undergoing a series of drastic changes, one of the main causes is the accelerated growth of the population. According to the United Nations (2019), the population in 1950 was approximately 2,600 million people, whereas in 2011 the population had increased to more than 7,000 million people. Analysing the growth curve, it is expected that in 30 years time the population will increase by another 2,000 million people. As an outcome, the accelerated growth of the population is directly affecting the wellness of the planet given that so many people need food, which directly affects the natural resources, and in turn, generates negative results on the environment. Over time, as a result of the global population growth, the environment has been gradually degraded. The use of chemicals, deforestation, fossil fuels, and industrial and domestic waste are some of the most polluting activities that businesses and consumers are facing. The result is excessive consumption of natural resources, global warming, loss of biodiversity, and water and air pollution, which seriously threaten human and animal life (Baris, Harald, \& Rösch, 2015). As a result, environmental responsibility is increasingly important for consumers, as it affects lifestyles and consumption patterns (Rademaker \& Royne, 2018). In other words, those environmental challenges have led to an increase in ecological awareness, forcing many companies and nations to undertake new actions and practices in conjunction with the private sector in order to promote sustainable consumption. Therefore, investment in the environment and the development of new eco-technologies have been very important and have prompted the creation of different strategies to counteract the negative effects on the planet. However, each of these strategies serves a different purpose, like eco-label attri- 
butes on food packages. With these labels, food companies intend to be more socially accepted and strive to obtain social legitimacy or simply generate added value in a market as competitive and changing as the current one (Anwar \& Jan, 2016; Seyfang \& Longhurst, 2013). Nonetheless, individual activities can play a more prominent role as a driver of green decision-making than corporate environmental policies (Rademaker \& Royne, 2018).

Eco-labeling is part of the Green marketing strategies that boost green consumption behaviour. Green consumption has been strongly questioned because it has many interpretations; it has been related to socially responsible consumption, ecologically conscious consumption, environmentally responsible consumption, environmentally friendly consumption, and pro-environmental consumption (Miranda Cuéllar \& Fonden Calzadilla, 2019; Nguyen, Nguyen, \& Hoang, 2019). Moreover, as Nguyen, Nguyen and Hoang (2019) stated, the term "consumption" implies, in part, destruction and consumerism, whereas the term "green consumption" implies the wellness of the people instead of individual needs. Some initiatives also being developed in terms of marketing include the design strategies of different enterprises in relation to green consumption, where the model "win-win" between the environment and the profits of these companies is the main goal. Furthermore, enterprises begin to understand the behaviour of thier consumers who want to consume green products. Moreover, green consumption has become relevant for both developed and developing countries alike. However, developing countries have more problems than developed countries in terms of adopting the important consumption model of buying green food products.

As Fagang (2019) pointed out, the values that generate green consumption and the main influence for people to eat green products is knowing the benefits for the environment. Also, Fagang (2019) explains that consumers perceive the effectiveness of their actions when them buy and consume green products. Then, for them it is important to know whether they are doing some important for the environment because the impact is remarkable. While people feel that their actions help the environment and create more conscious for more people are encouraged to act in the same way. Fagang (2019) reached an important conclusion: it was demonstrated that a correlation between environmental values and green consumption behaviour exists through internal attitudes and external normative factors. As previously mentioned, eco-labeling is a powerful instrument to synchronize information among companies and consumers in order to find solutions to the many environmental issues.

\section{Intrinsic Variables}

\section{Consumer Environmental Awareness}

"Consumer awareness is intended to reflect consumers' recognition of the existence of eco-labels" (Taufique, Siwar, Talib, Sarah, \& Chamhuri, 2014, p. 2182). There are many authors who refer to this variable as an important factor in consumer perception of eco-labels; Schubert, Kandampully, Solnet, and Kralj (2010) found that in the US, consumers believe that restaurants can and should help protect the environment and they are willing to pay more in restaurants with eco-friendly products, practices, and actions. Later, Yan and $\mathrm{Xu}$ (2010) showed in their study that the green purchasing behaviour is established in the early stages of development, so the family plays the most important role in consumer socialization, as parents communicate to their children their beliefs and preferences for buying green products. In addition, some groups of consumers are particularly concerned about waste, and are likely to spend more money on an environmentally friendly product if it reduces the usage of energy by means of simpler packaging and recycling innovations (Royne, Levy, \& Martinez, 2011); in other words, the consumer is willing to pay more for a product with eco-packaging. However, "individual consequences related to the amount of effort and the convenience of consumers are negatively related to the intention of buying green products" (Ramayah, Lee, \& Mohamad, 2010, p. 1423).

During 2014, two studies concluded that different levels of environmental responsibility moderate the impact of socially responsible consumption behaviour on the purchase intent, considering that consumers will engage in greener purchasing behaviours when their perception of the seriousness of the environmental problems and the environmental responsibility sharpens, and/ or when their concern for self-image towards environmental behaviour augments (Dagher \& Itani, 2014; Nasir \& Karakaya, 2014); suggesting that if environmental awareness increases, so will green consumption.

\section{Consumer Environmental Knowledge}

Kaufmann, Panni, and Orphanidou (2012) argue that there are three factors that can affect consumers' green purchasing behaviour: collectivism, environmental concern, and perceived consumer effectiveness. They are highly interrelated and should be integrated as a basis for ensuring the safety of the assessment that the consumer performs in regards to the label that directly influences the verification process of eco-labels. "The presence of strict standards for organic food, the reliability of foreign certifications, and the higher perceived quality of foreign 
products (especially from Europe) are togetherperceived as a security guarantee" (Bruschi, Shershneva, Dolgopolova, Canavari, \& Teuber, 2015, p. 418), given that consumers with greater environmental awareness are more difficult to convince about the veracity of the ecological attribute.

\section{Product Benefits}

Nasir and Karakaya (2014) suggest that there are two main benefits that consumers like: utility and health. Consumers like to buy eco-labeled food products when they perceive them to be useful, valuable, beneficial, and wise. Health benefits are more influential, compared to environmental awareness, in determining the preference for consuming eco-food and the greater green purchase behaviour. Consumers perceive that purchasing eco-friendly products is a demanding and stressful activity, but this negative variable is external to a significant negative influence on green purchase intention and behaviour, given that, what consumers want to find in a product are features like accessibility, affordability, and awareness (Barbarossa \& De Pelsmacker, 2014).

\section{Extrinsic Variables}

\section{Eco-label Type I}

According to Taufique et al. (2014, p. 2180), Type I eco-labels "are normally voluntary schemes that are verified by a third party and based on multi-criteria that grant licenses to use the label/logo of that scheme for specific products or services that meet prescribed standards based on a life cycle assessment (LCA)". For consumers, eco-label certifications are relevant when choosing a good green product and determining willingness to pay. In a study conducted by Janssen and Hamm (2012) in Europe, it was found that the European Union logos and government certification logos encourage more consumer perception than private logos, and a large number of logos attracted a greater willingness to pay among frequent buyers of organic food compared to occasional buyers. In the specific case of Italy, "people are willing to pay the highest price for a product with a Protected Designation of Origin (PDO) label, followed by a product with an organic farming label, and then by a product with a Protected Geographical Indications (PGI) label" (Aprile, Caputo, \& Nayga, 2012, p.159).

\section{Demographic Variables}

For the consumer, the selfish attributes of the product are of vital importance. Characteristics such as low price, familiar facilities or well-known brands are very important in the decision making, which is based on self-serving motives and are compared with the attributes of the green products. In this way, the attributes of the green products are in fact important for the purchase intention when self-serving motives are fulfilled. On the other hand, when a product has biosphere values and green attributes, the influence is higher than the selfish values.

In the research carried out by Grunert, Hieke and Wills, (2014, p.181) the demographic variables play an important role in the purchasing decisions of consumers in Europe:

"Women are more concerned about sustainability and use labels more often than men, but there is no difference in the level of understanding. Older people have higher levels of concern, but lower levels of understanding and use. Higher social classes report greater use of sustainability labels, but social class has no effect on the level of concern or understanding. Having children has, perhaps surprisingly, no influence. Higher education leads to higher levels of understanding and use, but not to higher levels of concern".

In agreement with that, Chen, Lobo and Rajendran (2014) argue that gender moderates the relationship between attitudes and purchase intent, the level of education is not significantly related to purchase intent, and the higher the income, the more likely a consumer is to buy eco-labeled products; adding that younger consumers have more money to spend and prefer to do their shopping in supermarkets where eco-food products are available.

\section{Purchasing Decision}

According to Chatzidakis, Hibbert, and Smith (2007, p. 93), the "Theory of Planned Behaviour (TPB) suggests that personal values, moral standards, internal ethics, and other similar factors drive the purchasing intentions of ethical consumers", to the extent that behaviour is the result of intention and the ability of making a conscious decision (Ham, Jeger, \& Frajman Ivkovic, 2015). Based on this, Carrington et al., (2010) presented a conceptual model in which the intention to implement plans, the actual behavioural control, and the situational context mediate the ethical intention-behaviour gap of consumerism; the first two positively moderate behaviour and the latter can act positively or negatively. Later, Grimmer and Miles (2017) empirically tested this conceptual model and it was partially supported, with the only exception that the situational context did not seem to influence the effect of the plans. As a result, it was found that there are both intrinsic and extrinsic variables that influence between the eco-label purchase intent and the actual purchase behaviour as shown in Figure 1. 


\section{Methodology}

The methodology that was used consisted of a literary review; the investigation process began approximately in mid-May 2017, determining the variables that make change the positive intent to purchase eco-labeled food products and the actual purchase behaviour. As a result, the general search reviewed databases such as EBSCO, ProQuest, JESTOR, and ScienceDirect. Keywords included to carry out the research were: green consumer behaviour, perceptions and intentions of the green consumer, eco-labels, and purchase decision. In the articles, the different variables were in the decision of purchasing eco-labeled products. This study had a qualitative scope to analyse the data among consumers for eco-labeled food products. There were 15 semi-structured interviews which were undertaken in Bogota Colombia (see appendix A). As was pointed out by Venkatesh, Brown and Bala, (2013), qualitative research has a very particular characteristic due to the degree of interpretation and analysis to understand the different phenomenon in marketplace. The authors also point out that indicators of quality include validity, accuracy, credibility and transferability. Validity is the capacity of the research instrument to quantify the data in a meaningful and appropriate way; accuracy refers to what is reported by the researchers; credibility establishes that the findings are credible from the point of view of the participants; and transferability is the degree to which the results can be generalized to the population or in other contexts. The main question to answer in this study is: to what extent understand the influence of intrinsic and extrinsic variables on the purchase intention behaviour gap for eco-labeled food products could reduce this space? Also, the four premises include: a) p1: The influence of product benefits on purchase intention of eco-labeled food products; b) p2: The influence of consumer environmental knowledge on purchase intention of eco-labeled food products; c) p3: The influence of consumer environmental awareness on purchase intention of eco-labeled food products; d) $\mathrm{p} 4$ : the influence of eco-label type I on purchase intention of eco-labeled food products, and e) p5: The influence of demographic variables on purchase intention of ecolabeled food products (see figure 1).

\section{Findings and Discussion}

Green purchasing behaviour is the consumption of environmentally friendly products that are sensitive, responsive, recyclable, and beneficial to the environment (Mostafa, 2007); this green movement is increasing due

Figure 1. Variables between intention and behaviour, adapted from Ajzen and Fishbein (1980)
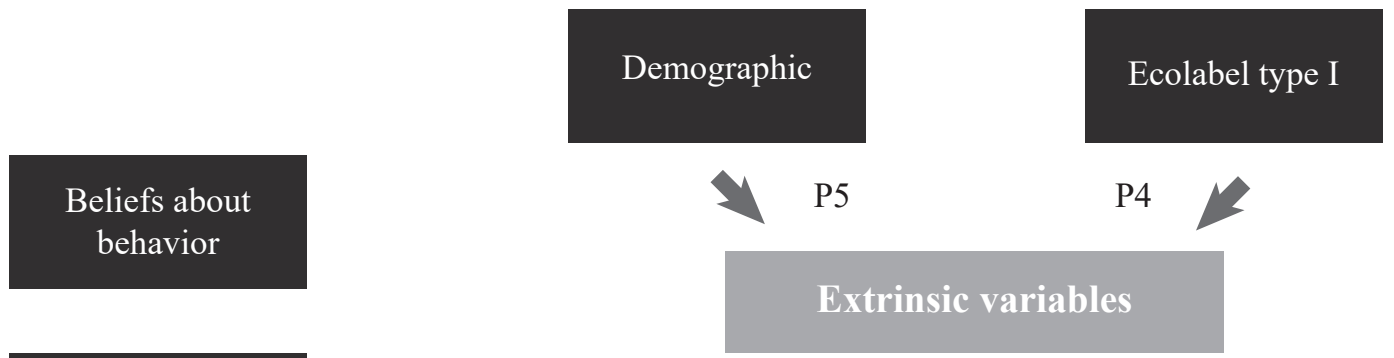
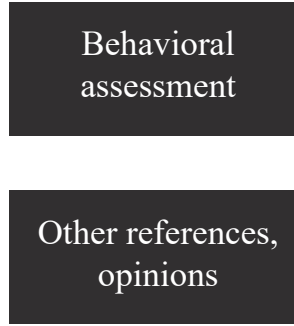

Motivation to fulfil
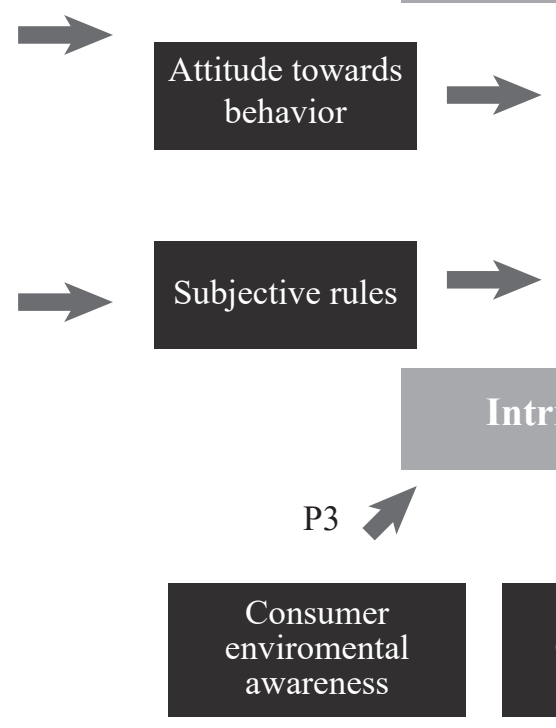

\section{Intrinsinc variables}
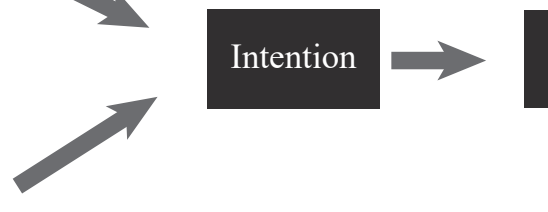

Behaviors (purchase)

Source: Elaborated by the author. 
to the large number of eco-labeled products on the market. According to Durif, Boivin, and Julien (2010, p.25), an eco-label is a "visual communication tool that indicates environmentally preferable products, services or companies that are based on standards or criteria". According to this, researchers have had to evaluate how much consumers understand about eco-labels in order to comprehend the gap between green purchasing intention and actual purchasing behaviour; an evaluation that was carried out by using the model proposed by Ajzen \& Fishbein (1980) as the main model through the Theory of Reasoned Action (TRA), which postulates that the intentions and behaviours of individuals are formed by a combination of the individuals' perceived behavioural controls, subjective norms, attitudes, and referents as independent variables (Dagher \& Itani, 2014).

\section{Qualitative Results}

The qualitative results will be addressed from the coded answers for each question referenced in the in-depth interview and subsequently codified from the hypothesis to be tested in the present study. These analyses used the software Atlas.ti. In order to respect the answers of the interviewees, what they stated will be textually left in the language of origin, in this case, Spanish. The qualitative answers were analysed and classified in the five variables: private benefits, environmental knowledge, environmental awareness, eco-label type I, and demographic variables.

In terms of Product Benefits, the answers can be summarised as follows:

P1: the influences of product benefits on purchase intention of eco-labeled food products.

Some participants identified specific characteristics of the products (foods) that they take into account when buying them.

Natural:

"That it is a national product, that it has a consumption date of no more than one month, and if possible that they are not canned products, that they are for domestic preparation"

"When I am buying food I prefer that they are natural products, that they do not contain preservatives chemicals"

Price - Quality:

"The expiration date, the price, and now that I think about it, sometimes the brand."

"Well, the quality and the price, basically, that there is a balance between both the quality and the price. I think that is the main thing for me."
"Quality really depends on what one tries and likes, or the things that are recommended, but in the end, one always buys what he likes.

In terms of Consumer environmental knowledge, the answers can be summarised as follows:

P2: Consumer environmental knowledge influences purchase intention of eco-labeled food products.

Some participants consider that the recycling of food packaging is a good solution to mitigate environmental impact.

Recyclable:

"Well, I'm not the healthiest person, but we should try to consume things that have no packaging; vegetables, for example, are things that have less packaging, so at least you're saving the amount of packaging."

"Well, I would say that if we do not know how to recycle or dispose of the food package in an appropriate way, yes, of course, this can cause negative impact"

"Well, the truth is that I only look at the issue of packaging; when I buy something there are some packages that use the minimum amount of plastic, so I try to consume those products. That is the only thing I really looked at."

"Of course, if we do not use recyclable packaging and elements that are biodegradable, we directly impact our environment."

"Yes, I believe that if you know what you are doing wrong and that we are damaging the environment and we do not know how to recycle, then obviously, it is directly proportional to the damage on the environment."

In terms of Consumer environmental awareness, the answers can be summarised as follows:

P3: The influence of consumer environmental awareness on purchase intention of eco-labeled food products.

Some participants take into account that the packaging of food products is recyclable or biodegradable at the time of purchase, but the label is not taken into account; in addition, other participants consider that the production and consumption of food have an environmental impact.

"The environmental problems are serious, however, man seeks alternative solutions in order to solve them; for example, alternative wind and solar energy. I am very concerned about global warming due to the melting of the poles; the rising sea levels."

"People can help in various ways, one of them would be recycling garbage, wasting less water, turning off the lights before leaving, using the same car to transport several people, etc."

"It is a serious problem that must be addressed through culture so that we all take care of the environment. Yes, 
pollution because it affects our health and it obviously destroys the planet."

"People are not aware ofrecycling, of how to save the environment. In the future we may be affecting our children or the young people by not recycling."

In terms of ecolabel type I, the answers can be summarised as follows:

P4: The influences of eco-label type I on purchase intention of eco-labeled food products.

"That the products which have these types of labels, or packaging that can be reused or can be used for other types of things, may be more expensive for companies and may be more expensive for the consumer. For this reason, it would be a big problem for consumers if the products were even more expensive."

"They are not very visible, I think there is no awareness of the label, of what it is about because many people do not know what it means."

"Negative things like the price, since the price of these products is often increased when they have this type of label."

"If I know that the ecological label is on certain products and I know that this type of packaging will be reused in different ways, and it will not become waste, that it helps the environment, then obviously I'm going to keep buying it. I think there would be no negative aspect to the eco-label if people know what it means."

"I think that there is a lack of education regarding labels on recycling products, many people do not know what they mean. It would be an advantage because it helps people make a better decision."

"They should do more advertising campaigns in favor of the recycling label."

"I have never paid much attention to eco-labels on food products, that's the truth."

One participant indicated that he takes into account the eco-label in his process of buying food products. However, some participants pointed out that they do not take into account the eco-label in their product purchase process. Also, applicants indicate that the higher cost of the eco-labeled products discourages them from their purchase; nevertheless, others participants identify the ecological type I recycling label but others do not know about ecological recycling label. At the same time, the interviewees suggested strategies for communication and visualization of eco-labels in order to gain greater knowledge about them. Other general conclusions of eco-label answers include: (a) few participants consider (assume) that the purchase of food products with eco-labels contributes to reducing the environmental impact of their packaging, (b) some interviewees consider that the purchase of food products with eco-labels (type I recycling) helps reduce the environmental impact of their packaging by encouraging recycling, and (c) interviewees consider (assume) that food products with eco-labels correspond to environmental measures implemented by the companies to reduce the environmental impact of their packaging.

In terms of demographic variables, the answers can be summarised as follows:

P5: The influence of demographic variables on purchase intention of eco-labeled food products.

The respondents were concentrated into socioeconomic strata 3 and 4, which represents $70 \%$ of the total, while other strata represent the remaining $30 \%$ of the sample. Also, there is a large concentration of interviewees who are between 20 and 50 years of age $-81.5 \%$ of the sample. In addition, the segment that is most important is that of 20 to 30 years of age, with $42.6 \%$. In the sociodemographic variable level of studies, the highest percentage is $55.6 \%$ with a university degree followed by $22 \%$ with postgraduate diplomas, and very few respondents only had a high school degree. It can be concluded that most of the young people between 20 and 30 years old have graduated from university, live in socioeconomic strata 2 and 3, and $70 \%$ of the respondents were women.

In conclusion, according to the analysis of the in-depth interviews, it can be understood that the variables are related for the premises P1, P2, P3 and P5. In other words, those variables: product benefits, consumer environmental knowledge, consumer environmental awareness, and demographic aspects, have influence on or affect the intention to purchase for food with ecological labels. On the other hand, the only premise where the stated variables have no relationship was $\mathrm{P} 4$; therefore, the ecolabel type I has no significant relationship with the intention to purchase for food with eco-label attributes.

\section{Conclusions and Future Research}

Qualitative results confirm that product benefits such as the price and nature of the product are significant, which explains the influence on purchase intention. In terms of consumer environmental knowledge, some participants consider the recycling of packaging as a good solution to mitigating the environmental impact. On the other hand, in terms of consumer environmental awareness, the interviewees consider that the processes of production and consumption of food products have a negative environmental impact. Moreover, the eco-label type I is only important for one interviewee at the moment of purchasing a food product with an eco-label, but for the rest of the interviewees this attribute is not important in the process of intention and purchasing of eco-labeled products. 
Finally, demographic variables are important to close the gap for eco-label food products because gender, education level and age are fundamental when closing the gap.

The managerial implications for companies that are in the food sector are very significant because their marketing departments can better understand the influence of the variables classified as intrinsic and extrinsic between the intention and decision to buy the products with ecological labels. It is very likely that many marketing managers do not completely understand this influence given that the results of the market research show that consumers say that they would be willing to buy eco products, but the reality is totally different. These results help to better understand the factors that the marketing strategy should focus on so that consumers actually buy the environmentally friendly products. Additionally, the qualitative comments of the in-depth interviews that provide valuable information to the marketing managers will be pointed out. The qualitative outcome information was classified in the main aspects: sensitization - visibility and confidence when the interviewer asked them: Do you have any suggestions for the companies that use these labels on food products?

The responses were directly translated:

Sensitization - Visibility

"I think that there is a lack of education regarding labels on ecological and recycled products. Many people do not know about the labels and this could be an advantage because it helps people to make a better choice."

"That they use recyclable packaging that is not plastic, but that they can start using friendly packaging. I know that they are making packaging out of rice, they are making different packaging with materials that are more degradable, so companies should think about this and take advantage of everything."

"A negative aspect is that they are using these labels, but it takes a lot of campaigning for people to understand what the labels are for."

"That they do more advertising campaigns in favour of the recycling labels."

"I don't know. Maybe that they are as more visible, and more understandable, maybe with an explanation or something, so one knows what the little arrows stand for and people can understand that they help us contribute to the environment. They need to be more visible."

\section{Confidence}

"Well, sometimes you see these multinationals talking about the environment, using all these labels and such, but deep down I don't know, what are they really doing, sometimes they aren't really doing much, sometimes it is all about advertising, but in the background they aren't doing much."
"I don't pay attention to the labels in my purchase process, that's the truth because I am supposed to buy things that have that type of label in order to know that it can be recycled and reused, but the truth is that I don't pay much attention to the labels."

"It doesn't influence me much when choosing a product, but it does influence me when I recycle it."

To sum up, regardless of whether green consumerism has increased, there is still a large gap between the ecolabel purchase intent and the actual purchase behaviour (Carrington et al., 2010; Cleveland et al., 2005; Englis \& Phillips, 2013; Devinney et al., 2010; Papaoikonomou et al., 2011); therefore, this study focused on finding the variables that could reduce the gap and affect the relationship between intention and behaviour (Carrington et al., 2010). The goal was to collect and synthesize these findings in order to understand how these variables affect behaviour, and to classify them into intrinsic and extrinsic variables. For further research, it is recommended to investigate these variables in the Americas, since most of the research has been developed in European countries; only one study was found to have been developed in Brazil. It is also important to understand that due to the fact that demographic variables are moderators of behaviour, and these differ radically in the different countries, this research permitted us to determine a pattern of behaviour by comparing the independent variables. In this way, the research can say that making a comparison can change the final variables between intention and behaviour, and that for this reason it is necessary to expand the level of research to other countries in the world.

\section{References}

Ajzen, I., \& Fishbein, M. (1980). Understanding attitudes and predicting social behaviour. Englewood Cliffs, NJ: Prentice-Hall.Akehurst, G., Afonso, C., \& Martins, E. (2012). Re-examining green purchase behaviour and the green consumer profile: New evidences. Emerald insight, 50(5), 972-988. doi: 10.1108/00251741211227726

Anwar, A., \& Jan, S. (2016). Consumer attitude towards the marketing-mix of the green products. International Journal of Research in Commerce \& Management, $7(2), 86$.

Aprile, M. C., Caputo, V., \& Nayga Jr, R. M. (2012). Consumers' valuation of food quality labels: The case of the European geographic indication and organic farming labels. International Journal of Consumer Studies, 36, 158-165. doi: 10.1111/j.1470-6431.2011.01092.x

Barbarossa, C. \& De Pelsmacker, P. (2014). Positive and negative antecedents of purchasing eco-friendly products: A comparison between green and non-green 
consumers. Journal of Business Ethics, 134, 229. doi:10.1007/s10551-014-2425

Baris, Y., Harald, S., \& Rösch, A. (2015). Green segmentation: A cross-national study. Marketing Intelligence \& Planning. (Bradford Tomo 33, N. ${ }^{\circ}$ 7, 981-1003). doi: 10.1108/MIP-12-2013-0201

Bruschi, V., Shershneva, K., Dolgopolova, I., Canavari, M., \& Teuber, R. (2015). Consumer perception of organic food in emerging markets: Evidence from Saint Petersburg, Russia. Agribusiness, 31(3), 414-432. doi: 10.1002/agr.21414

Carrington, M., Neville, B., \& Whitwell, G. (2010). Why ethical consumers don't walk their talk: Towards a framework for understanding the gap between the ethical purchase intentions and actual buying behaviour of ethically minded consumers. Journal of Business Ethics, 97(1), 139-158. Retrieved from http://www. jstor.org/stable/40929378

Chan, R. Y. K. (1999). Environmental attitudes and behaviour of consumers in China: Survey findings and implications. Journal of International Consumer Marketing, 11(4), 25-52.

Chan, R.Y.K., \& Lau, L. B.Y. (2000). Antecedents of green purchases: A survey in China. Journal of Consumer Marketing, 17(4), 338-357.

Chatzidakis, A., Hibbert, S., \& Smith, A. P. (2007). Why people don't take their concerns about fair trade to the supermarket: The role of neutralisation. Journal of Business Ethics, 74(1), 89-100.

Chen, J., Lobo, A., \& Rajendran, N. (2014). Drivers of organic food purchase intentions in mainland China Evaluating potential customers' attitudes, demographics and segmentation. International Journal of Consumer Studies, 38(4), 346-356. doi: 10.1111/ijcs.12095

Cleveland, M., Kalamas, M., \& Laroche, M. (2005). Shades of green: Linking environmental locus of control and pro-environmental behaviours. Journal of Consumer Marketing, 22, 198-212.

Dagher, G. K. \& Itani, O. (2014). Factors influencing green purchasing behaviour: Empirical evidence from the Lebanese consumers. Journal of Consumer Behaviour, 13(3), 188-195. doi: 10.1002/cb.1482

Dagher, G. K., Itani, O. S., \& Kassar, A. (2015). The impact of environmental concern and attitude on green purchasing behaviour: Gender as the moderator. Contemporary Management Research, 11(2), 179-206.

Devinney, T. M., Auger, P., \& Eckhardt, G. M. (2010). The myth of the ethical consumer. New York, NY: Cambridge University Press.

Diamantopoulos, A., Schlegelmilch, B. B., \& Sinkovics, R. R. (2003). Can socio-demographics still play a role in profiling green consumers? A review of the evidence and an empirical investigation. Journal of Business Research, 56(6), 465-480. doi: http://dx.doi. org/10.1016/S0148-2963(01)00241-7

Durif, F., Boivin, C., \& Julien, C. (2010). In search of a green product definition. Innovative Marketing, 6(1), 25-33.

D’Souza, C., Taghian, M., \& Khosla, R. (2007). Examination of environmental beliefs and its impact on the influence of price, quality and demographic characteristics with respect to green purchase intention. Journal of Targeting, Measurement and Analysis for Marketing, 15(2), 69-78.

Englis, B. G. \& Phillips, D. M. (2013). Does innovativeness drive environmentally conscious consumer behaviour? Psychology and Marketing, 30(2), 160-172.

Fagang, Hu. (2019). The impact of environmental values on consumers' green consumption behaviour. Journal of Agricultural Sciences, 108, 2243-2247.

Finisterra do Paço, A. M., Barata Raposo, M. L., \& Filho, W. L. (2009). Identifying the green consumer: A segmentation study. Journal of Targeting, Measurement and Analysis for Marketing, 17(1), 17-25.

Follows, S. B., \& Jobber, D. (2000). Environmentally responsible purchase behaviour: A test of a consumer model. European Journal of Marketing. Available online: http://www.epa.gov/greenerproducts/glossary

Grimmer, M., \& Miles, M. P. (2017). With the best of intentions: A large sample test of the intention-behaviour gap in pro-environmental consumer behaviour. International Journal of Consumer Studies, 41(1), 2-10. doi: 10.1111/ijcs.12290

Grunert, K. G., Hieke, S., \& Wills, J. (2014). Sustainability labels on food products: Consumer motivation, understanding and use. Food Policy, 44, 177-189. Doi: 10.1016/j.foodpol.2013.12.001

Ham, M., Jeger, M., \& Frajman Ivkovic, A. (2015). The role of subjective norms in forming the intention to purchase green food. Ekonomska Istrazivanja/ Economic Research, 28(1), 738-748.

Hartmann, P., \& Ibáñez, V. A. (2006). Green value added. Marketing Intelligence \& Planning, 24(7), 673-680.

Janssen, M., \& Hamm, U. (2012). Product labelling in the market for organic food: Consumer preferences and willingness-to-pay for different organic certification logos. Food Quality and Preference, 25(1), 9-22.

Kaufmann, H. R., Panni, M. F. A. K., \& Orphanidou, Y. (2012). Factors affecting consumers' green purchasing behaviour: An integrated conceptual framework. Amfiteatru Economic, 14(31), 50.

Kuhl, J., \& Beckmann, J. (1985). Action control. From cognition to behaviour. Heidelberg: Springer-Verlag.

Laroche, M., Bergeron, J., \& Barbaro-Forleo, G. (2001). Targeting consumers who are willing to pay more for 
environmentally friendly products. Journal of Consumer Marketing, 18(6), 503-521.

Miranda Cuéllar, R. L., \& Fonden Calzadilla, J. C. (2019). Indicadores de evaluación del desempeño ambiental en una organización cubana. Revista Ingeniería Industrial, 17(2), 149-170. Doi: org/10.22320/ S07179103/2018.09

Mohr, L. A., \& Webb, D. J. (2005). The effects of corporate social responsibility and price on consumer responses. Journal of Consumer Affairs, 39(1), 121-147.

Mostafa, M. M. (2007). Gender differences in Egyptian consumers' green purchase behaviour: The effects of environmental knowledge, concern and attitude. International Journal of Consumer Studies, 31(3), 220-229.

Nguyen, H. V., Nguyen, C. H., \& Hoang, T. T. B. (2019). Green consumption: Closing the intention-behaviour gap. Sustainable Development Journal, 27(1), 118-135.

Nasir, V. A. \& Karakaya, F. (2014). Underlying motivations of organic food purchase intentions. Agribusiness, 30(3), 290-308. Doi: 10.1002/agr.21363

Papaoikonomou, E., Ryan, G., \& Ginieis, M. (2011). Towards a holistic approach of the attitude behaviour gap in ethical consumer behaviours: Empirical evidence from Spain. International Advances in Economic Research, 17(1), 77-88.

Pomering, A. \& Dolnicar, S. (2009). Assessing the prerequisite of successful CSR implementation: Are consumers aware of CSR initiatives? Journal of Business Ethics, 85(2), 285-301.

Pujari, D., Wright, G., \& Peattie, K. (2003). Green and competitive influences on environmental new product development performance. Journal of Business Research, 56(8), 657-671. Doi: 10.1016/S01482963(01)00310-1.

Rademaker, C. A., \& Royne, M. B. (2018). Thinking green: How marketing managers select media for consumer acceptance. The Journal of Business Strategy, 39(2), 30-38. Doi: 2138/10.1108/JBS-05-2017-0070

Ramayah, T., Lee, J. W. C., \& Mohamad, O. (2010). Green product purchase intention: Some insights from a developing country. Resources, Conservation and Recycling, 54(12), 1419-1427.
Rowlands, I. H., Parker, P., \& Scott, D. (2002). Consumer perceptions of green power. The Journal of Consumer Marketing, 19(2/3), 112-129.

Royne, M. B., Levy, M., \& Martinez, J. (2011). The public health implications of consumers' environmental concern and their willingness to pay for an eco-friendly product. Journal of Consumer Affairs, 45(2), 329-343. Doi: 10.1111/j.1745-6606.2011.01205.x

Seyfang, G., \& Longhurst, N. (2013). Growing green money? Mapping community currencies for sustainable development. Ecological Economics Journal, 86, 65-77.

Schubert, F., Kandampully, J., Solnet, D., \& Kralj, A. (2010). Exploring consumer perceptions of green restaurants in the US. Tourism and Hospitality Research, 10(4), 286-300.

Tanner, C. \& Kast, S.W. (2003). Promoting sustainable consumption: Determinants of green purchases by Swiss consumers. Psychology \& Marketing, 20(10), 883-902.

Taufique, K. M. R., Siwar, C., Talib, B., Sarah, F. H., \& Chamhuri, N. (2014). Synthesis of constructs for modelling consumers' understanding and perception of eco-labels. Sustainability, 6(4), 2176-2200.

United Nations (2019). Emissions gap report 2019. Retrieve from https://www.unenvironment.org/resources/emissions-gap-report-2019

Venkatesh. V., Brown. S., \& Bala, H. (2013). Bridging the qualitative-quantitative divide: Guidelines for conducting mixed methods research in information systems. MIS Quarterly, 37(1), 21-54.

Vermeir, I., \& Verbeke, W. (2006). Sustainable food consumption: Exploring the consumer 'attitude-behavioural intention' gap. Journal of Agricultural and Environmental Ethics, 19(2), 169-194.

Vermillion, L. J. \& Peart, J. (2010). Green marketing: Making sense of the situation. Proceedings of the Academy of Marketing Studies, 15(1), 68-72.

Yan, R. \& Xu, H. (2010). Understanding green purchase behaviour: College students and socialization agents. Journal of Family and Consumer Sciences, 102(2), 27-32. 


\section{Appendix A. In-Depth Interview that was applied to Consumers}

1. What do you understand by environment?

2. What do you think of the problems associated with the environment?

3. Do any of these problems concern you? Why?

4. In what ways do you think people could help solve environmental problems?

5. In your opinion, do you think that food consumption is related to environmental problems? Why?

6. What aspects do you take into account when choosing a product in the supermarket?

7. Do any of the above contribute to solving environmental problems?

8. What do you know about eco-labels on food products?

The eco-label is taught and the following questions are asked:

9. What is your opinion regarding this eco-label?

10. How is this label present in your purchase process?

11. What would you suggest to companies that use these labels on food products?

12. What positive and negative aspects do you identify in products with an eco-label?

13. What do you think are the biggest problems in making eco-labeled products more important in your purchases? 